\title{
Penguasaan dan Pemilikan Tanah yang Diskriminatif: dalam Perspektif Hukum Internasional dan Hukum Nasional
}

\author{
Jawahir Thontowi
}

\begin{abstract}
This essay reveals that indigenous people such as Indian people in America and Aborigine in Australia find it difficult to culturally and socially integrate with white people who are colonizers. Some cases of state conflict relating to the land dispute have placed a vital role in which neighbors countries are involved in the arms conflict or wars. It is not because the absence of the law to handle dispute, rather the political interest of certain country predominate to treat the case unjustly as demonstrated in Palestine case. In relation to the current situation, the Australian and Indonesian govemment concem very much to improve land reform for the interest of the people by issuing certain laws and regulations. In fact, however, the Australian govemment currently recognizes the Native Title Act for Aborigine to occupy and own their own land in conjuction with their own beliefs' and myths. The positive development takes place in Indonesian, not only. because the presence of the state platform of guideline and the law No 22/1999 concerning the local autonomy, but also due to the people welfare, the govemment requires to implement the basic principle of agrarian law. It is in fact, however, uneasy to implement it because the practice of the state of local autonomy is challenged by intemal problems of professional workers and also in certain territories, such as Yogyakarta, is uneasy to fully adhere the law because of its special treatment.
\end{abstract}

\section{Pendahuluan}

Pentingnya tanah secara kosmologis dalam masyarakat bukan sekedar tempat di mana mereka tinggal, melainkan juga tempat dari mana mereka berasal dan akan ke mana pula mereka pergi. Itulah sebabnya menurut Elizabeth Cash bahwa perbincangan tanah di masyarakat tradisional (berburu dan nomaden), lebih banyak, dipergunakan istilah territoriality (kewilayahan) sebuah konsep ekologis yang menggambarkan adanya penggunaan tanah dan bukan pemilikan (Iand tenure $)^{1}$

'Elizabet Cashdan (ed.). 1989. Hanters and Gatherers; Economic Behaviour in Bands in Stuart Platther (ed). Economic Antropology Stanford Calitornia: Stanford University Press. HIm. 40. 
Jean Jacques Rousseau, telah menempatkan persoalan pemilikan tanah rakyat sebagai bagian dari teori kontrak sosialnya (social contract). Dalam menentukan hak atas sebidang tanah penting dipertimbangkan siapa yang menghuni pertama kalinya. Secara hukum kedudukan penghuni pertama diakui sebagai pemiliknya bilamana memenuhi persyaratan. Pertama, tak ada seorangpun yang menempati tanah tersebut sebelumnya. Kedua, tanah itu dikuasai hanya sekedar untuk memenuhi kebutuhan bukan komoditi. Ketiga, proses pemilikan tidak ditentukan oleh sekedar upacara ritual, melainkan terdapat bukti atas pemilikan yang wajib dihormati oleh orang lain. ${ }^{2}$

Prinsip penguasaan dan pemilikan atas tanah di atas juga berlaku pada zaman dulu. Terutama dalam wujud kaidah-kaidah normatif yang diperoleh dari kebiasaan suatu masyarakat tertentu. Akan tetapi, dalam kenyataannya prinsip-prinsip pemilikan yang didasarkan kepada asas hukum siapa yang pertama kali menemukan dan menghuni tampak menjadi kurang valid. Hal ini terutama terjadi ketika bangsa-bangsa Eropa melakukan ekspansi ke beberapa benua lainnya, seperti benua Amerika, dan Australia.

Sejarah ekspansi teritorial bukan saja telah meninggalkan kesan negatif masyarakat terjajah terhadap para penjajah, melainkan juga telah menumbuhkan terciptanya benihbenih peraturan hukum mengenai penguasaan dan pemilikan tanàh yang diskriminatif. Dua kategori pendatang baru (Migrator and Conquror) dan penduduk asli sebagai pribumi (indigeneous) dalam suatu masyarakat menjadi persoalan menarik dalam kaitannya dengan penguasaan dan pemilikan tanah di indonesia. Apalagi penguasaan dan pemilikan tanah tampak menjadi lebih komplek ketika pemerintah pusat memberi wewenang kepada daerah-daerah untuk melaksanakan otonomi daerah secara luas.

Tulisan ini berusaha menjelaskan berbagai kontradiksi peraturan hukum, dalam kaitannya dengan pemilikan dan penguasaan tanah yang diskriminatif di dalam masyarakat. Peristiwa diskriminasi penguasaan dan pemilikan tanah itu tidak saja akan dianalisis melalui fakta sejarah yang ditemui di benua Amerika dan Australia, melainkan akan dianalisis juga mengenai situasi penguasaan tanah yang sering menimbulkan konflik dan peperangan antara bangsa. Persoalan itu juga menjadi penting ketika indonesia sedang berada di dalam kekuasaan pemerintah kolonialisme Belanda maupun setelah Indonesia merdeka. Tampaknya Daerah istimewa Yogyakarta akan menjadi salah satu daerah yang bisa menggambarkan bagaimana peranan UU No 5 Tahun 1960 tentang UndangUndang Pokok Agraria tidak mudah diterapkan.

\section{Konflik antara Negara dan Penguasaan Tanah.}

Tidak jauh berbeda awal kolonisasi masyarakat Eropa yang dipimpin oleh Christoper Columbus sampai ia menemukan salah satu bagian di Amerika Selatan, sekitar 1502-1504. ${ }^{3}$ Kedatangan Columbus ternyata

\footnotetext{
2Jean Jacques Roesseau. 1986. Political Wrtings. Terjemahan Frederick Watkins. Madison: The Univesity of Wisconsin Press. HIm. 22.

${ }^{3}$ Selintas mengenai Columbus bisa dilihat The Encyclopaedia. Ibid: Vol. III. HIm. 476.
} 
juga tidak mendapatkan perlakuan yang baik. Masyarakat Indian merasa tidak menghendaki, kekuatan kolonial Eropa menduduki bumi Amerika. Masyarakat Indian yang masih primitif terbunuh dalam peperangan dengan orangorang Eropa yang telah memiliki perlengkapan senjata modern. Salah satu faktor utama sikap penolakan dari bangsa Indian tersebut adalah karena mereka menganggap bahwa tanah itu merupakan suatu bentuk harta kekayaan yang memiliki nilai-nilai ekonomis.

Perang antara Argentina dan Inggris sekitar 1982 sebenarnya mengantarkan situasi di mana hutan yang belum terpelihara oleh negara bekas jajahan bisa diklaim oleh negara bekas penjajah. Dalam sejarah peralihannya, pulau Malvinas tersebut telah dijual oleh Prancis kepada Spanyol setelah sebelumnya dikuasai oleh Inggris sejak tahun $1765 .{ }^{4}$ Karena itu, sebagaimana dikatakan oleh Rubin, kedudukan pulau Malvinas tersebut telah menjadi medan pertengkaran antara negara-negara kolonial Prancis, Inggris dan Spanyol sejak abad ke delapan belas.

Begitu juga konflik masyarakat Palestina mengenai status kota suci Jerussalem yang diduduki dan dianeksasi sejak 1948 -1967. Sejak beberapa abad kedudukan Palestina merupakan bagian kekuasaan Islam di bawah kesultanan Turki. Baru pada 1917 terutama ketika terjadinya perang dunia pertama, ditempatkan. Palestina di bawah mandat penguasaan kerajaan Inggris. Berdasarkan Pasal 22 Piagam Liga Bangsa-Bangsa, keberadaan penduduk sebagai negara merdeka dan karenanya Palestina merupakan suatu negara yang berada di bawah naungan dan kedaulatan hukum internasional.

Tugas yang diberikan Liga Bangsa-Bangsa kepada Inggris dengan menempatkan Palestina sebagai negara mandat tidak pemah tercipta hingga akhir abad ini. Tidak sedikit usaha-usaha yang dilakukan dari segi hukum internasional telah diberikan dengan maksud untuk melindungi kedudukan willayah Palestina. Misalnya, penulis perjanjian Versailles telah memberikan inspirasi kepada negara-negara tersebut untuk menentukan nasib mereka berdiri sendiri (self determination).

Pasal 181 Resolusi PBB tanggal 29 November 1947 menyatakan kedudukan hukum Jerusalem sebagai tempat terpisah yang secara administratif berbeda di bawah naungan PBB. Akan tetapi, usaha-usaha bersifat juridis dari PBB tidak lebih effektif ketimbang perjuangan politis negara-negara yang berkepentingan. Sebagaimana di catat oleh Henry Cattan, seorang hakim internasional Universitas Jerusalem, melaporkan bahwa sejak Inggris diberi mandat oleh Liga Bangsa-Bangsa, imigrási besar-besaran orang-orang Israel ke Palestina telah berlangsung cukup lama. Peningkatan penduduk Yahudi di Jerusalem dari 99,690 (sembilan puluh sembilan ribu enam ratus sembilan puluh orang) pada 1946 menjadi 280,00 (dua ratus delapan puluh orang) pada 1985 dibandingkan dengan penduduk Palestina 120,00 (seratus dua

4Alfred P. 1985. Rubin Historical and Legal Background of the Falkland/Malvinas Dispute in Call and Anthony Arend (ed). The Falklands Warlesson for Strategy. Diplomacy and Intemational. Boston: George Allen \& Unwin. HIm. 12. 
puluah orang) telah menunjukan cukup bukti kuat adanya hubungan positif antara dominasi politik dengan hukum. ${ }^{5}$

Dengan kata lain, peranan Inggris untuk melindungi kedudukan Palestina telah gagal dalam mengemban tugas dan tanggung jawab sebagai negara mandat dari Liga BangsaBangsa. Sebaliknya pendudukan pengungsi dan pengubahan keadaan demografis di Jerusalem telah terjadi besar-besaran pada masa Inggris. Bukan hanya sekedar peranan Inggris, justru kaitan sejarah pertanahan peradaban yang terjadi di sekitar masyarakat Arab dan sekitarnya tidak lepas dari peraturan hukum Romawi di Jerusalem masa lalu.

Suatu pendekatan sejarah geografis seperti dijelaskan oleh Michael Avi Yonah cukup signifikan untuk dipertimbangkan dalam kaitannya dengan status hukum kota suci Jerusalem. Relevansi tersebut antara lain, bahwa pelacakan sejarah kronologis mengenai suatu wilayah bisa menjadi sumber keterangan yang penting dalam membangun suatu hipotesis. Kedua bahwa temuan-temuan arkeologis termasuk adanya persaingan antara peradaban yang satu dengan yang lain (Jerusalem-Romawi dan negara statusnya) bisa menjadi alat bukti penting bagi suatu putusan. Ketiga, hubungan pengaruh yang terlihat dalam aspek ekonomi, geografi, dan pendudukan sebenarnya dapat melacaknya terjadinya hubungan antara negara di mana usaha-usaha hukum acapkali gagal ketimbang kepentingan politik. ${ }^{6}$

Berdasarkan beberapa kasus di atas, pendudukan Amerika maupun yang terjadi di Palestina dan Malvinas menunjukan buktibukti bahwa tanah sebagai tempat pemukiman (resettlement), dan komoditi ekonomi telah menjadi ajang timbulnya konflik dan bahkan peperangan antar bangsa.

\section{Doktrin Penguasaan dan Beberapa Perubahan Penting di Australia}

Terjadinya pemukiman di Australia diperkirakan yaitu sekitar 25,000 sampai dengan 40,000 tahun silam mereka diperkirakan datang dari Asia Tenggara. Pada sekitar abad ke delapan belas ditemukan sekitar 300,000 (tiga ratus ribu orang) penduduk yang tinggal di benua Australia. Kerajaan Inggris mengirim utusan sekitar 1644, namun tidak pernah tiba hingga James Cook mampir dalam pelayarannya di New Southwales 1770. Proses kolonisasi Inggris ke Australia secara keseluruhan baru dicapai sekitar tahun 1803, yaitu ketikaAustralia Barat mulai dihuni bersamaan dengan ditemukannya pertambangan tembaga dan emas.

Sikap masyarakat asli Aborigin tidak asimilatif dengan kedatangan bangsa Eropa Masyarakat Aborigin memilih bertahan daripada melakukan kontak hubungan

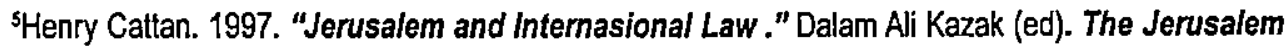
Question. Canberra: general Palestine Delegation. HIm. 12-13.

${ }^{8}$ Pelacakan hubungan sejarah ekonomi, geografis dan penduduk di tanah Suci Jerusalem telah dilakukan studi mendalam oleh Michael Avi Yonah. 1977. The Holy Land : From The Persian To The Arab Conquest. (536BC. - AD 640)AHistorical Geography. Michingan: Baker Book House. HIm. 188-211. 
dengan orang-orang kulit putih. Kegagalan pemerintah kulit putih untuk mengasimilasikan mereka berakibat timbulnya ketegangan sosial yang berkelanjutan. Usaha pembebasan tanah yang tadinya dianggap keramat oleh masyarakat Aborigin-tidak dihiraukan lagi oleh penguasa kulit putih. Menurunnya jumlah suku Aborigin lantaran mereka telah menjadi korban dari kekerasan kolonialisme tidak terhindarkan. Ini logis sebab orang kulit putih yang dalam masa awal pemukiman adalah bangsa sebagai para narapidana. Sensus resmi pada 1986, menunjukkan bahwa jumlah suku Aborigin kurang dari sekitar 228,000 (dua ratus dua puluh delapan ribu orang). Jumlah itu cenderung menurun lantaran mereka tergolong masyarakat miskin, kebanyakan mereka tergolong penganggur. ${ }^{?}$

Pada dasarnya status tanah dalam doktrin hukum Inggris (the common law) menyatakan bahwa kedaulatan untuk menguasai dan menentukan tanah di Australia dikuasai oleh raja. Penguasaan dan berbagai kepentingan atas tanah telah diyakini oleh raja sejak hari pemukiman dimulai selama itu juga menjadi dasar dari usaha mengelaborasi undangundang mengenai penyewaan dan penjualan tanah.

The feudal doctrine of tenure from the Crown applies in Australia, and land not alienated by the crown, including mines reserved from a crown grant, are in the actual possession of the crown, so that an information of intrusion will lie againts a person who intrudes on such land without consent of the crown. ${ }^{8}$.

Berdasarkan pernyataan di atas', pertama, bahwa feodalisme terlihat dalam kedudukan seorang raja sebagai penguasa dan pemilik tanah. Kedua, bahwa apa-apa yang terkandung dalam perut bumi berada pada penguasaan raja. Ketiga, pemindahan penguasaàn tanah termasuk penggunaan isi kandungan tanah demi kepentingan rakyat dilindungi oleh raja sehingga penguasa masyarakat, terhadap tanah tanpa izin raja bisa dianggap sebagai pelangaran.

Doktrin tersebut tidak selalu dapat diterapkkan sebab setiap pemilikan tanah atas dasar perolehan melalui pemindahan mestinya tetap menjadi pemilik aslinya the Ancient owner, that is, of the Aboriginal inhabitants. ${ }^{9}$ Karena itu dalam batas tertentu, raja harus melindungi hak pemilikan tanah bagi pribumi.

Untuk menetapkan dan mengembalikan hak pemilikan tradisional bagi masyarakat Aborigin terbukti memerlukan waktu yang panjang. Beberapa alasan mengapa hak penguasaan tanah di suku Aborigin tidak terlepas dari kebijakan politik orang kulit putih White Collour Policy. Pada tahun 1970-an sehingga pemilikan tanah yang diskriminatif tetap berlangsung. Dasar hukum penempatan tanah milik suku Aborigin tersebut yaitu berkaitan dengan sejarah penundukan orang Eropa sekitar dua abad yang lalu. Benua Aus-

\footnotetext{
${ }^{7}$ Gambaran umum bisa dilihat dalam bab Australian Aborigin. 1992. The New Encyclopaedia Britanica. Vol.I Founded 1768 (15th Edition). Chicago: Encyclopaedia Britanica Inc. Hilm. 714.

8W.N harrison. 1965. Coses On the Law Australia The Law Book Company Limites. HIm. 63.

'/bid. HIm. 68.
} 
tralia dianggap sebagai tanah-tanah yang tidak ada pemiliknya, (terra nulius). Jikapun Australia dianggap ada penduduknya itupun tidak lain dianggap sebagai suatu kelompok yang belum memiliki organisasi sosial (Stateless). Sehingga mereka dianggap oleh orang Eropa tidak memiliki hak pemilikan atas bendabenda yang ada. ${ }^{10}$

Adanya penuntutan yang dilakukan atas penggunaan tanah Aborigin oleh pengusaha pertambangan tidak pernah terjadi seiama 180 tahun. Suatu kasus yang pertama kali timbul, yaitu ketika masyarakat Aborigin menggugat penggunaan tanah untuk pertambangan almunium dan bouksit. Gugatan suku Aborigin terhadap Navalco (1971), perusahaan almunium melalui pengadilan ditolak. Hakim Blacburn dari Mahkamah Agung, Negara bagian Darwin menolak gugatan Aborigin karena, hukum kebiasaan Inggris tidak mengakui doktrin hukum pemilikan tanah untuk penduduk asii.

Situasi hukum di Australia telah mengalami perubahan yang cukup mendasar. Perubahan ini terjadi terutama setelah terdapat preseden hukum atas masyarakat Aborigin yang mengklaim hak atas sebidang tanah karang di selatan pulau Torest. Putusan hakim Blacksburn di Darwin mulai diragukan validitasnya. Adanya pengakuan atas hak tanah Aborigin, terutama didasarkan kepada putusan pengadilan tinggi mengenai Mabo di Queensland. Putusan kasus Mabo tersebut merupakan preseden hukum kuat, terutama setelah keluarnya undang-undang hak milik bagi penduduk asli yang dikeluarkan pada 1993 oleh pemerintah federal.

Ada beberapa alasan yang perlu dikemukakan hakim untuk mengabulkan tuntutan masyarakat Aborigin. Pertama, terdapat kesalahan tafsir dalam memahami peradigma "tidak ada hukum" bagi masyarakat Aborigin (The absence of Law) dan "barbaris". Konsekuensinya, anggapan bahwa pemerintah kolonial memiliki kekuasaan untuk mengakui Australia atas prinsip res nullius tidak bisa diterapkan. Di dalam perlembagaan zaman modern, penghuni yang berasal sebagai penjajah, dalam kehidupan mereka tidak bisa dipergunakan untuk memperkuat argumen res nullius." Dengan ditanggalkannya doktrin terra nullius, maka ketiga bentuk penguasaan tanah, seperti pengakuan melalui kedaulatan (acession to sovereign) pendudukan (conquest) penyerahan dan pemukiman (cession and settlement) bisa dipergunakan untuk menjelaskan adanya hak pemilikan atas suku asli sebelum penjajah berkuasa.

Perdana Menteri Paul Keating menegaskan bahwa pandangan hakim tinggi atas adanya putusan Mabo merupakan peristiwa penting dalam hubungan antara penduduk asli dan masyarakat Australia. Pandangan politis Keating juga didukung oleh landasan hukum yang-kuat. Setidak-tidaknya ada 4 (empat) segi penting yang terdapat dalam UU Suku Asli 1993 (Native Title Act).

a. Pengakuan terhadap hak-hak pemilikan suku asli.

${ }^{10}$ Kerry Mulqueen. 1996. Sue aliever and athei : Survival of Judigenous Legal Rights (Chaper II). Australia: Darwin Faculty of Law. Northern Territory University. Hlm. 1.

"I/bid. 1996. HIm. 45. 
b. Pengaturan terhadap kesahihan bukti, seperti jaminan atas tanah dan seberapa jauh hukum bisa "membatalkan ketidakabsahan adanya hak-hak suku asli.

c. Suatu kekuasaan yang adil untuk yang akan datang tetap harus memberikan jaminan terhadap peraturan hak-hak suku asli.

d. Pendirian .peradilan tuntutan suku asli untuk suatu perundingan dan pengurusan untuk jaminan atas hak-hak tanah suku asli, serta dibuatnya proses peradilan dengan menentukan upaya hukum naik banding dalam kaitannya hak suku asli. ${ }^{12}$

Jelaslah, bahwa doktrin peralihan kekuasaan, termasuk pengambilan melalui argumen tera nullius tidak bisa dipertahankan lagi.

\section{Perubahan Penguasaan Tanah di Australia}

Perubahan pemilikan: penguasaan dipengaruhi oleh beberapa faktor di luar kebijakan hukum dan politik Australia. Dari segi hukum Internasional, penaklukan penyerahan dan pendudukan (occupation) terhadap suatu wilayah yang dinyatakan terra nulius adalah termasuk tiga casa yang paling efektif dalam memperoleh kedaulatan wilayah. Dalam kaitannya dengan perjajah Eropa, mereka melakukan pengambilalihan atas tanah yang penghuninya amat terbelakang. Perubahán terhadap cara penentuan kedaulatan terutama dengan lahirnya gerakan misionary orang Eropa terhadap masyarakat yang telah berlangsung sejak abad pertengahan.
Model kedua; pengakuan kedudukan teritorial suatu tanah sebagaimana dikatakan oleh hakim Pengadilan Tinggi, 'melalui caŕa pengadilan di mana teritorial baru bisa diklaim bilamana tanah tersebut tidak pernah ditanami (uncultivaled'). Dalam kàsus oràng Australia, tanah di sekitar New South Wales, bisa diberikan dengan model perigambilalihan. Ketika penduduk asli tidak pernah berusaha menjadikan tanah-tanah yang tidak ditanami tersebut menjadi produktif.. ${ }^{13}$ -

Berdasarkan pada pandangán hakim di PT Australia, dapat banyak hal yang ditemukan sebagai bukti atas kedudukan tanah dan proses penguasaan antara orang-orang kulit putih dan masyarakat Aborigin. Namun, yang perlu ditegaskan sebenarnya terdapat dua golongan besar. Pertama, pendatang Eropa sekitar abad ke delapan belas, atas nama kerajaan Inggris bisa menuntut hak peralihan atas tanah. Hal ini tentu bisa dibenarkan baik oleh hukum internasional maupun nasional, bilamana tanah-tanah yang kosong, untuk dipergunakan sehingga menjadi produktif.

Kedua, pengakuan negara terhadap hakhak penguasaan dan pemilikan tanah masyarakat Aborigin, untuk kepentingan pertanian, pemukiman atau untuk kepentingan di luar itu, karena unsur keramat, suci (sacral). Perubahan sikap pemerintah Australia terhadap suku Aborigin ini, tidak lepas karena adanya kekuatan putusan pengadilan tinggi, termasuk MA yang membatalkan adanya doktrin terra nullius terhadap klaim masyarakat Eropa atas tanah Australia.

12/bid. HIm. 7.

${ }^{13}$ Lebih luas lihat Report of Cases Determined in the high court of Australia. 1992 June CLRS. HIm. 32. 
Faktor kedua yang menekankan timbulnya perubahan sikap pemerintah Australia terhadap masyarakat asli adalah semakin intensifnya kampanye HAM di kalangan masyarakat Aborigin terhadap pemerintah. Kampanye ini mulai lebih efektif terutama ketika disepakatinya Discrimination Convention Act, dan pemerintah Australia termasuk negara yang menandatangani konvensi tersebut. Atas dasar itu, Undang-Undang Diskriminasi Rasial, (Racial Discrimination Act 1975) menjadi sumber acuan hukum penegak hukum dan masyarakat. ${ }^{14}$

Memperhatikan faktor-faktor timbulnya pengakuan terhadap hak-hak masyarakat pribumi, maka bisa dilihat dengan jelas bagaimana kehendak politik pemerintah. Menurut suatu komentar dan penjelasan dari UU Hak Milik Pribumi (Native Title Act) 1993, Januari 1994, menyebutkan bahwa Putusan Pengadilan Tinggi di Queensland (No. 2) memiliki kepastian hukum yang jelas. Oleh karena itu, pemerintah harus mengakui hakhak dasar dari suku asli pribumi.

Setiap hak penguasaan tanah secara adil atas masyarakat asli wajib diakui selagi tuntutan mereka disadarkan hukum adat dari suku asii.

Suku asli tersebut adalah mereka yang telah memelihara hubungan atas ikatan leluhur dan tanah kelahiran mereka.

Hak-hak milik mereka tidak bisa dimusnahkan oleh adanya kehadiran imperialisme, penjajah atau kepanjangan dari kedaulatan pemerintah negara persemakmuran.

UU Hak Milik Pribumi ini membatalkan berbagai penalaran hukum yang selama ini dijadikan dasar kebijakan politik pemerintah Australia. Misalnya, pertama doktrin terra nullius harus ditolak karena tidak sesuai dengan kenyataan sejarah.

Kedua, adanya sistem hukum kebiasaan dan praktik masyarakat asli Aborigin sebagai landasan hukum mereka tidak bisa dikalahkan oleh .kehadiran orang-orang Eropa. Pemindahan penguasaan bisa saja terjadi ke tangan raja asalkan ada proses penyerahan secara sukarela sesuai dengan adat istiadat hukum masyarakat asli.

Ketiga, Undang-Undang mengenai Diskriminasi Rasial 1975 dalam Pemerintahan Persemakmuran terbukti besar pengaruhnya. Misalnya, Pasal 9 menegaskan bahwa suatu tindakan menjadi terlarang bagi seseorang yang melakukan perbuatan dan yang didasarkan kepada golongan, dan berpengaruh terhadap pengaruh rasa senang akan hak-hak dasar dan kemerdekaannya golongan tertentu. Pasal 10 menyatakan bahwa seseorang berdasarkan hukum suatu golongan menyebabkan golongan lain merasa tidak senang atau terganggu, maka dengan penerapan pasal ini, seseorang yang merasa dirugikan harus diperlakukan secara sama. ${ }^{15}$

Atas dasar kedua pasal tersebut, perlindungan hukum masyarakat Aborigin atas

${ }^{14}$ Penjelasan Lebih Lanjut bisa dibaca di "Report of Case 1992. Ibid. HIm. 70.

${ }^{15}$ Secara lebih tuntas masalah ini diabaikan di dalam Attorney General's Departement, NATIVE.TITLE: legislation with commentary by the Attorney General's legal practice. Australia. ANAGPS. Press Publication 1993. Him. C4-C5. 
tanah semakin mendapat kepastian hukum. Adanya kepastian hukum tersebut bukan saja dapat membatasi kekuasaan eksekutif termasuk raja di Inggris, melainkan bagaimana peranan pengadilan secara efektif bisa menghilangkan adanya sistem hukum yang diskriminatif terhadap masyarakat Aborigin.

\section{UUPA dan Konvensi ILO}

Hukum internasional memiliki pesan terhadap pengakuan hak-hak lokal masyarakat Indonesia. Ketentuan-ketentuan hukum seperti peraturan Menteri atau Surat Edaran Menteri yang tidak menjamin hak-hak masyarakat lokal perlu diperbaharui. ${ }^{16}$

Dengan adanya Konvensi Internasional No. 169 mengenai kedudukan tanah yang dikeluarkan pada 27 Juni 1989, oleh Organisasi Buruh Internasional (ILO), maka usaha ke arah perbaikan status tanah lokal makin terjamin. Akan tetapi, ketentuan ini kurang efektif dalam menciptakan kesejahteraan masyarakat karena sikap pemerintahan Orde Baru kurang peduli terhadap Konvensi ILO 169/1989 dalam membuat kebijakan hukum tanah. ${ }^{17}$

Yando Zakaria menegaskan bahwa kelemahan UUPA disebabkan adanya pengakuan kedudukan hak adat dan agama secara sejajar menjadi nafas lahirnya undangundang. Tetapi, pengakuan tersebut tidak secara jelas diikuti langkah-langkah operasional. Sehingga kekuatan pembangunan ekonomi kapitalis dapat dengan mudah menggeser kedudukan hak-hak adat itu. Hal ini terbukti dengan tumbuhnya kontrakdisi antara UUPA dan undang-undang atau peraturan lainnya atas penguasaan tanah untuk kepentingan usaha nasional.

Terdapat beberapa peraturan yang terlihat kontradiksi satu sama lain. Pertama, PP No. 21 Tahun 1970 tentang Hak Pengusaha dan Hak Pemungutan Hasil Hutan. Hak-hak adat yang ada di dalamnya diberlakukan meski dalam konsiderasinya, hak-hak adat diakui oleh UUD 1945.

Kedua, Keputusan Menteri Kehutanan No. 251/KPTS/11/1993, ketentuan Pungutan Hasil Hutan oleh masyarakat Hukum Adat atau anggota dalam wilayah Hak Pengusahaan Hutan. Keputusan ini, ternyata hanya berlaku bagi golongan suku tertentu. Berarti peraturan tersebut secara substansial cacat karena mengandung unsur diskriminasi. Atas dasar pengakuan pluralisme hukum, mestinya negara memberikan perlindungan atas hak-hak masyarakat, termasuk hak-hak adat tersebut.

Ketiga, Undang-Undang. Adanya Kontradiksi antara UU No. 5 Tahun 1960 dan UU No. 11 Tahun 1967. Sifat kesejajaran antara UU No. 5 Tahun 1960 dengan UU No. 11 Tahun 1967, tentang Ketentuan Pokok-Pokok Peraturan Pertambangan menempatkan kedua undangundang tidak ada yang lebih dominan. Penggunaan tanah oleh negara yang bertujuan untuk kepentingan umum dapat berlangsung ketika pemerintah Orde Baru berkuasa, selalu

${ }^{18}$ A.P. Perlindungan. 1998. Hukum Agraria: Beberapa Pemikiran dan Gagasan. Hermawan Sauni. Yamani Komar (ed). Medan: Penerbit Universitas Sumatra Utara. HIm. 98.

${ }^{17} \mathrm{R}$. Yando Zakaria dan Djaka Soehendra. 1997. Reformasi Agraria: Perubahan Politik, Sengketa dan Agenda Perubahan Agraria di Indonesia. Jakarta: Lembaga Ekonomi- UI. HIm. 181-186. 
menjadi faktor yang paling efektif dalam memenangkan UU No: 11 Tahun 1967 Pertambangan.

Sebaliknya di dalam era reformasi terdapat nuansa baru yang lebih demokratis. Lahirnya UU No 22 Tahun 1999 merupakan bukti kongkrit perubahan positif tersebut. Akan tetapi, lahirnya UU No 22 Tahun 1999 tidak terlalu mudah dalam penerapannya dikaitkan dengan UUPA. Suatu peraturan yang dianggap oleh banyak faktor hukum sebagai undangundang yang merakyat. Adanya kesesuaian antara semangat reformasi dengan peranan UUPA terlihat dari ketentuan GBHN 1998 dan UU No. 22 Tahun 1999.

Dalam GBHN 1998 disebutkan bahwa pembangunan bidang pertanahan diharapkan mendukung hal-hal sebagai berikut:

a. Memperkokoh persatuan dan kesatuan nasional

b. Pemberdayaan ekonomi masyarakat

c. Memperluas kesepakatan berusaha serta meningkatkan lapangan kerja melalui pemerataan pemilihan tanah.

d. Penguasaan dan penggunaan tanah bagi masyarakat secara adil yang didukung oleh tertib dan penegakan hukum.

e. Tertib administrasi dan penggunaan tanah berdasarkan keterangan RT. RW.

f. Menjamin keseimbangan pemanfaatan tanah secara terpadu dengan tetap menjaga kelestariannya.

Meskipun ketentuan GBHN tersebut di atas dianggap kondusif dalam usaha menciptakan masyarakat yang lebih adil dan berbagai tantangan mengenai realisasi otonomi daerah tidak bisa diabaikan.

Di satu pihak, otonomi daerah tersebut direalisasikan dengan menekankan kepada prinsip-prinsip demokrasi, peran serta memperhatikan potensi dan keanekaragaman Daerah. Penyelenggaraan otonomi daerah dimaksudkan sebagai pemberian wewenang yang luas, nyata, dan bertanggung jawab kepada dasar-dasar secara proporsional yang diwajibkan dengan pengaturan, pembagian dan pemanfaatan sumber daya nasional, serta Perimbangan Keuangan Pusat dan Daerah sesuai dengan prinsip-prinsip demokrasi, peran serta masyarakat, pemerataan dan keadilan serta potensi dan keanekaragaman Daerah, yang dilaksanakan dalam kerangka Negara Kesatuan Republik Indonesia. ${ }^{18}$

Di pihak lain, adanya kajian-kajian parsial mengenai otonomi daerah yang mengisyaratkan adanya hambatan yang bakal timbul. Misalnya, Bung Hatta menegaskan sebagai berikut:

1. Adanya kewenangan-kewenangan di Daerah paling atas, dan paling lemah pada Daerah paling bawah.

2. Belum berfungsinya Dewan Pertimbangan Daerah dalam memberikan pembinaan.

3. Adanya anggapan bahwa banyaknya daerah otonomi mengalihkan indikasi tingkat demokrasi di daerah. Padahal sebenarnya tidak demikian. ${ }^{19}$

Selain itu, hambatan otonomi daerah terletak pada sistem pemerintahan yang tidak

${ }^{18}$ Baca Dasar-dasar Pemerintah dari UU No 22 Tahun 1999 tentang Otonomi Daerah.

${ }^{19}$ Sujamto. 1990. Otonomi Daerah yang Nyata dan Bertanggung Jawab. Jakarta: Ghalia Indonesia. HIm. 176. 
mampu memainkan tiga fungsi yaitu pengendali, pelaksanaan dan operasional. Kejelasan kaitan fungsi pemerintah pusat sebagai pengendalian Pemerintah Daerah Tingkat I sebagai pelaksanaan, Pemerintah Pusat dengan Daerah Tingkat II yang mengoprasionalkan pembangunan di daerah. Oleh karena itu, jika ketiga fungsi itu berjalan dengan baik, maka reaksi otonomi daerah tersebut yang seimbang akan segera terlaksana. Akan tetapi, pengaturan ketiga fungsi Pemerintah (Pusat, Propinsi dan Kabupaten) tidak jelas, maka kecil kemungkinan otonomi daerah bisa diterapkan. Dengan kata lain, diskriminasi dalam bidang hukum, politik dan ekonomi akan tetap berperan bilamana peningkatan profesionalisme bagi aparat pemerintah daerah tidak ditingkatkan.

Sejalan dengan itu, hasil penelitian Erman Rajagukguk mengenai persoalan hukum agraria masih tetap relevan untuk diperhitungkan dalam kaitannya dengan realisasi UUPA dengan otonomi daerah. la menegaskan, dengan mengandalkan pada pejabat-pejabat desa, yang didominasi oleh partai politik dalam pelaksanaan land reform, tanah tidak diperoleh oleh orang yang tidak mempunyai tanah, tetapi oleh keluarga-keluarga, atau orang-orang yang dekat pada kelompok elit desa. ${ }^{20}$ Setidaktidaknya, bilamana partai politik saat ini tidak akan terlalu dominan dalam pembagian tanah-tanah justru ikatan-ikatan geneologis kesukuan dan elit-elit desa tidak mudah untuk dikendalikan.

Akar persoalan yaitu, adanya kesulitan daerạh untuk sepakat dan sepaham baik dalam arti konsep sosial maupun operasional, dalam melaksanakan titik berat otonomi pada Daerah Tingkat ' $1 \mathrm{I}{ }^{21}$ Termasuk aparat pemerintah tingkat kecamatan dan kelurahan/ pedesaan yang tidak mudah merealisasikan Undang-Undang Otonomi Daerah termasuk pembagian tanah yang adil bagi peningkatan kesejahteraan ekonomi rakyat

\section{Realisasi Otonomi Daerah di DIY}

Sebenarnya bagaimana mengkritisi persoalan hambatan yang timbul di DIY ketika UU Otonomi Daerah direalisasikan. Bisakah nilai-nilai diskriminatif yang melembaga pada masyarakat dihapuskan. Persoalan melembaganya nilai-nilai diskriminatif dalam hukum baik mengenai otonomi daerah maupun UUPA No 5 Tahun 1960 yang sukar diluruskan adalah terkait dengan beberapa Daerah yang berstatus Istimewa.

Secara khusus, persoalan otonomi daerah timbul disebabkan oleh adanya pengakuan khusus dari UU No.22 Tahun 1999, mengenai status DIY dan Daerah Istimewa Aceh tetap memiliki kekhususan dalam penyelenggaraan pemerintah Propinsi bagi DIY, kedudukan Gubernur dan Wakil Gubernur dijabat oleh keturunan .Sultan dan Paku Alam. ${ }^{22}$

\footnotetext{
${ }^{20}$ Erman Rajagukguk. 1995. Hukum Agraria, Pada Penguasaan Tanah dan Kebutuhan Hidup. Jakarta: Chandra Pratama. HIm. 17

${ }^{21 H . A . W . ~ W i d j a y a . ~ 1998 . ~ P e r c o n t o h a n ~ O t o n o m i ~ D a e r a h ~ d i ~ I n d o n e s i a . ~ J a k a r t a: ~ P e n e r b i t ~ R i n e k a ~ C i p t a . ~}$ HIm. $174-175$.
}

22Pasal 122, UU No 22 Tahun 1999 dan penjelasannya. 
Sebenarnya faktor-faktor apa yang bisa dikategorikan bahwa suatu daerah yang memiliki kekhususan atau keistimewaan. Menurut Soedarisman Poerwokoesoemo Daerah Istimewa adalah daerah yang mempunyai hak asal-usul dan yang mempunyai pemerintahan sendiri yang bersifat Istimewa di zaman sebelum Rl. Hak asal-usul adalah "Daerahnya", sedangkan yang mempunyai keistimewaan adalah "Pemerintahan". ${ }^{23}$

Pertama, hak asal-usul daerahnya dihubungkan wilayah penguasa geografis atau teritorial. Ketidakserasian antara UUPA dan peraturan perundang-undangan lainnya juga secara khusus terlihat dalam kasus pemilikan tanah di DIY. Tidak berlebihan proses otonomi daerah di DIY, khususnya dalam bidang pertanahan akan mengalami hambatan. Dalam satu segi DIY menerapkan peraturan yang agak khusus, oleh karena tidak sepenuhnya bisa menerima UUPA. Seandainya bisa diterapkan maka diperlukan adanya modifikasi, ini terutama berkaitan dengan status istimewa dan adanya perbedaan status pemilikan tanah bagi masyarakat.

Kekhususan lahimya yang relevan dalam kaitannya dengan hukum kebiasaan Yogyakarta yang raja sebagai pemilik tanah dan penguasaan atasnya. Pengakuan dari Presiden pertama, tertanggal 19 Agustus 1945, Ingkang Sinuwun Kanjeng Sultan Hamengku Buwono, Sinopati ing Ngalogo, Abdurrahman
Sasidin Panotogomo Kali fatullah ingkang kaping IX ing Ngayogyokartohadiningrat. ${ }^{24}$

Hak milik atas seluruh luas tanah di wilayah kerajaan adalah mutlak di tangan raja. Rakyat diberi hak meminjam " jangka waktu turun temurun". Tanah yang dipakai sendiri oleh Sultan. Tanah yang diserahkan kepada Belanda dan Tionghoa sebagai hak eigondom (HGB).

Kekhususan DIY dalam persoalan tanah terlihat dalam bukti pemilikan tanah sebgai berikut;

1. Di luar kota Praja Yogyakarta tanda bukti hak miliknya dibuat model $D$ (Perda No. 12. 1954).

2. Di dalam kata Sertifikat Tanahnya adalah Jatno Pustoko Keraton Ngayogyakarta; (Hak milik atau apa). Untuk tanah-tanah hak Barat diberi sertifikat menurut Pasal 19 UU melambangkan Garuda Indonesia.

Secara teoritis warga negara Tionghoa yang tinggal di DIY, sebenarnya berhak memiliki sebidang tanah yang diwariskan turun temurun asalkan mereka warga negara Rl. Sebagaimana dikatakan oleh Peraturan dan Perundangan tentang keagrarian di Daerah Istimewa Yogyakarta, hak milik perseorangan turun temurun hanya dapat diberikan kepada warga negara Rl. ${ }^{25}$

\footnotetext{
${ }^{23}$ Lihat Soedarisman Poerwokoesoemo. 1984. Daerah /stimewa Yogyakarta. Yogyakarta: Gajah Mada Press. HIm. 266.

${ }^{24}$ Nikmatul Huda. 1996. Status Tanah Keraton Yogyakarta setelah berlakunya UU No. 5 tahun 1960 di Propinsi Daerah Istimewa Yogyakarta. Yogyakarta. Fakultas Hukum Ull 1996. Ni'matul Huda 1996. HIm. 32.
}

${ }^{25}$ Monografi DIY Tahun 1979 Kantor Pusat Data Propinsi DIY. Hlm. 254. 
- Ketentuan inj tidak diskriminatif jika dibenarkan tanpa adanya tafsiran lain. Apakah WNI tersebut keturunan atau pribumi. Tafsiran ekstensif WNI keturunan bisa jadi menjadi salah satu sumber hukum kebiasaan, yang kemudian secara diam-diam diterapkan atau implied consent terhadap WNI keturunan. Konsekuensinya ada anggapan bahwa Tionghoa tidak bisa mengklaim hak milik atas tanah.

Ketentuan ini jelas diskriminatif, namun dalam praktiknya terdapat cara cara yang secara konvensional mampu menerobos ketentuan tersebut. Kedudukan WNI keturunan yang menerima HGB (Hak Guna Bangunan) untuk masa 20-30 tahun sebenarnya bisa memanfaatkannya untuk kepentingan ekonomi sekalipun HGB bagi Tionghoa sebenarnya berlaku relatif. Sebab, selain mereka bisa mewariskannya juga bisa dijadikan objek jual beli. Cara yang bisa dilakukan untuk menerobos HGB di kalangan Tionghoa DIY: Misalnya; bilamana HGB tersebut habis masa berlakunya, maka pengguna pertama memiliki hak prioritas untuk memperpanjang. HGB yang diperoleh seseorang bisa ditingkatkan menjadi hak milik bilamana memenuhi syarat. Misalnya pembebasan tanah-tanah rakyat oleh negara untuk perumahan dimungkinkan untuk ditingkatkan statusnya menjadi. hak milik. Hak seperti ini, tentu juga berlaku bagi WNI keturunan Tionghoa. Sebenarnya, jika tanah HGB milik negara, maka peningkatan status sangat tidak dimungkinkan

Kedua, istilah keistimewaan erat kaitannya dengan keberadaan pemerintahan yang dikaitkan dengan semangat demokratisasi tampaknya bertentangan. Kedudukan DIY sebenarnya kurang sesuai dengan asas demokrasi.
Keistimewaan DIY, dilindungi _secara konstitusional oleh perjanjian antara pemerintah setempat dan kolonial Belanda. Kedua, keistimewaan DIY oleh karena kontrak politik yang dibuat antara Sri Sultan Hameng kubuwono IX dan Gubernur Yogyakarta, LA. Adam tanggal 18 Maret 1940 dan disatukan oleh Gubernur Jendral Hindia Belanda, A.W.L. Tjarda Van Starkendorg.

Isi kontrak politik penting antara lain menegaskan sebagai berikut.

1. Penegasan tentang kedudukan kekuasaan daerah Kesultanan.

2. Penegasan tentang pembatasan kekuasaan Pemerintah Belanda dengan alat-alat kekuasaannya dan Kekuasaan Sri Sultan. Adanya ikatan hukum atau hak istimewa bagi DIY sebenarnya luhur dan meningkat sebagaimana UU karena adanya perjanjian.

Hak istimewa tersebut menjadi lebih kuat setelah pemerintah Indonesia pada awal kemerdekaan mengakui keberadaan DIY sebagai wilayah yang secara hukum dapat diperlakukan khusus. Menurut penjelasan UU No 1 Tahun 1957 tentang Pokok-Pokok Pemerintah Daerah, kepada daerah Istimewa ditegaskan bahwa dia tidak dipilih oleh dan dari anggota DPR, tetapi diangkat oleh Pemerintah Pusat dari keturunan keluarga yang berkuasa di daerah itu zaman sebelum itu. Ketentuan ini secara politis menguntungkan situasi DIY dalam menelihara identitas lokal. Namun kapan puterá daerah potensial bisa dipilih menjadi kepala Daerah Tingkat $/$ Propinsi dan bisa memiliki hák hukum sejajar. Otonomi daerah tidak akan efektif bila, the priciple of the equality all before the love tidak di terapkan. Karena itu, bilamana ketentuan 
hukum yang tertera di dalam sejarah perundangundangan sejak zaman Belanda hingga kini tidak menegakkan prinsip kesederajatan hukum dalam demokrasi, maka mekanisme pemerintahan DIY akan tetap bersifat diskriminatif.

Dengan demikian, bisa dipahami bahwa situasi diskriminatif di DIY memang diakui keberadaannya. Namun, dalam praktik bukan sekedar diskriminasi melainkan penyerobotan atas tanah-tanah Kraton tanpa izin telah berlangsung. Penataan pengaturan mengenai tanah di DIY yang sesuai dengan UUPA memang amat diperlukan sebab jika tidak, otonomi daerah tidak akan dapat direalisasikan sesuai dengan aspirasi masyarakatera reformasi.

\section{Simpulan}

Berdasarkan ketentuan hukum internasional maupun nasional, pendudukan, penempatan, dan pengambilan terhadap tanah-tanah yang tidak ada pemiliknya dengan maksud untuk diambil manfaatnya bisa dibenarkan keberadaannya. Namun, cara-cara tersebut dapat menimbulkan konflik bilamana tindakan penguasaan tanah tersebut melenyapkan status pemilikan bagi masyarakat pribumi. Timbulnya konflik-konflik antara bangsa sebagaimana terlihat dalam beberapa kasus masyarakat Indian di Amerika, masyarakat Palestina di Jerusalem, dan kepulauan Malvinas di Argentina menjelaskan fenomena bahwa penjajah cenderung diskriminatif dalam memperlakukan penduduk asli atau pribumi.

Perlakuan diskriminasi penguasaan dan pemilikan tanah oleh penjajah terhadap kaum pribumi di berbagai negara bukanlah merupakan preseden hukum baru: Fenomena diskriminatif tersebut bukan saja terkandung dalam ketentuan hukum material (substantif), melainkan juga karena penerapan peraturan hukum oleh penegak hukum melaksanakan tugas tidak berkesesuaian dengain peraturan hukum. Pemilikan tanah di Australia kebijakan pemerintah untuk menghilangkan unsur-unsur diskriminasinya tampak jauh lebih baik keberadaannya. Akan tetapi, jikapun ada kenyataan bahwa Tionghoa tidak bisa memperoleh tanah dengan seratus hak milik, maka tidak berarti bahwa kebijakan pemerintah DIY terhadap tanah bersifat diskriminatif sebagaimana di Australia.

Doktrin hukum Raja Inggris sebagai pemilik tanah di Australia telah diakui keberadaannya oleh sistem hukum kebiasaan (Common Law). Hal ini mengakibatkan masyarakat suku Aborigin kehilangan hak-hak pemilikannya selama beberapa abad atas tanah-tanah yang'mereka warisi dari nenek moyangnya. Perjuangan yang dilakukan oleh masyarakat Aborigin mulai kelihatan berhasil terutama ketika pemerintah Australia mengakui hak-hak pemilikan atas tanah-tanah mereka.

- Penguasaan dan pemilikan tanah yang diskriminatif di Australia, khususnya terhadap suku Aborigin mulai sirna sejak Hakim Blackburn di PT. Queensland mengabulkan gugatan mereka atas penolakan pemerintah. Keberhasilan tersebut, selain didukung oleh preseden hukum (jurisprudensi) pengadilan, juga tidak terlepas dari peranan Intervensi Konvensi Lembaga Internasional mengenai larangan diskriminasi antara golongan. Kepastian hukum bagi masyarakat Aborigin dalam penguasaan dan pemilikan tanah semakin kuat kedudukan setelah UndangUndang Hak Milik Pribumi (Native Title Act) diundangkan tahun 1993. 
Di Indonesia khususnya di Yogyakarta UUPA sebenarnya diundangkan selain memiliki nilai unifikatif dan populis juga sebenarnya berfungsi menghilangkan adanya diskriminasi dalam pemilikan dan penguasaan Tanah. Tapi dalam perkembangannya desakan pembangunan ekomomi, khususnya di dalam pemerintahan Orde Baru, begitu banyak peraturan perundang-undangan yang bertentangan dengan spirit UUPA. Beberapa ketentuan yang melindungi hak-hak adat termasuk pemilikan pribadi tergeser oleh karena lahimya peraturan hukum pertambangan dan penggunaan hutan yang tampak hanya memihak kepada kepentingan penguasa dan pengusaha.

\section{Daftar Pustaka}

Cashdan, Elizabet. 1989. Hanters and Gatherers; Economic Behaviour in Bands in Stuart Platther (ed). Economic Antropology Stanfood California: Stanford University Press.

Cattan, Henry. 1997. Jerusalem and Internasional Law in Ali Kazak (ed) The Jerusalem Question. Canberra: General Palestine Delegation.

Harrison, W.N. Coses Ont He Law Australia The Law Book Company Limites 1965.

Huda, Ni'matul. 1996. Status Tanah Keraton Yogyakarta setelah berlakunya UU No. 5 tahun 1960 di Propinsi Daerah Istimewa Yogyakarta. Yogyakarta: Fakultas Hukum UIl.

Mulqueen, Kerry. 1996. Sue aliever and ather: Survival of Judigenous Legal
Rights (Chaper II). Australia: Darwin Faculty of Law. Northem Territory University.

P, Alfred. 1985. Rubin Historical and Legal Background of the Falkland/Malvinas Dispute in Call and Anthony Arend (ed). The Falklands Warlesson for Strategy. Diplomacy and International. Boston: George Ailen \& Unwin.

Perlindungan, A.P. 1998. Hukum Agraria: Beberapa Pemikiran dan Gagasan. Hermawan Sauni. Yamani Komar (ed). Medan: Penerbit Universitas Sumatra Utara.

Poerwokoesoemo, Soedarisman. 1984. Daerah Istimewa Yogyakarta. Yogyakarta: Gajah Mada Press.

Roesseau, Jean Jacques. 1986. Political Writings. Terjemahan Frederick Watkins. Madison: The University of Wisconsin Press.

Rajagukguk, Erman. 1995. Hukum Agraria, Pada Penguasaan Tanah dan Kebutuhan Hidup. Jakarta: Chandra Pratama.

Sujamto. 1990. Otonomi Daerah yang Nyata dan Bertanggung Jawab. (Jakarta: Ghalia Indonesia.

Widjaya, H.A.W. 1998. Percontohan Otonomi Daerah di Indonesia. Jakarta: Penerbit Rineka Cipta.

Yonah, Michael Avi. 1977. The Holy Land: From The Persian To The Arab Conquest. (536BC. - AD 640) A Historical Geography. Michingan: Baker Book House. 
Zakaria, R. Yando dan Djaka Soehendra. 1997. Monografi DIY Tahun 1979 Kantor Pusat.

Kemajemukan Hukum, mengapa tidak?. Didalam Reformasi Agraria: Perubahan Politik, sengketa dan Agenda. Perubahan Agraria di Indonesia. Jakarta: Lembaga Ekonomi- Ull.
Report of Cases Determined in the high court of Australia. 1992 June CLRS.

The New Encyclopaedia Britanica. Vol.I Founded 1768 (15th Edition). Chicago: Encyclopaedia Britanica Inc. 